\title{
BICYCLE LANES DEVELOPMENT PLAN IN MATARAM CITY
}

\author{
Baiq Musfiatin \\ Master of Civil Engineering Program, Department of Civil Engineering \\ University of Mataram, West Nusa Tenggara, Indonesia
Buan Anshari, S.T., M.Sc(Eng)., Ph.D, Dr. Ir. I Dewa Made Alit Karyawan, M.T.
Department of Civil Engineering, University of Mataram,
West Nusa Tenggara, Indonesia

\begin{abstract}
Mataram City Government established a bicycle lane at Udayana Street as an alternative for all community to shift their motorized transport by bicycle as a daily transport and to support the NTB Cycling program from NTB Provincial Government. To accommodate changing mode of transportation from motorbikes or cars to bicycles, it is necessary to develop bicycle lanes in Mataram City. Vissim software used to forecast the impact of bicycles lane development at 9 provincial roads as the study area. From the analysis after implementation of bicycles lane development, there is a decrease in level of service based on Volume per Capacity Ratio. In addition, at signal intersection show an increase in queue length and vehicle delays. To minimize the impact of bicycles lane development, mitigation is carried out by rearranging the intersection cycle time. And the result is a reducing of $C O, N O x$ and $V O C$ emissions, fuel consumption, vehicle queue lengths and vehicle delays. Based on SWOT analysis, things that can affect respondent behavior to use bicycles is the existence of integrated route of bicycle lane with public transport service and supporting facilities (parking area, changing rooms) also regulations.
\end{abstract}

Keywords: Bicycle lanes planning, non motorized transport, vissim, swot

Cite this Article: Baiq Musfiatin, Buan Anshari and Ir. I Dewa Made Alit Karyawan, M.T., Bicycle Lanes Development Plan in Mataram City, International Journal of Civil Engineering and Technology, 11(8), 2020, pp. 68-77.

https://iaeme.com/Home/issue/IJCIET?Volume $=11 \&$ Issue $=8$

\section{INTRODUCTION}

\subsection{Background}

Bicycles as an alternative to non-motorized transport have various advantages, including not creating air and noise pollution, being more economical in terms of price and not requiring fuel. Creating an integrated friendly environmental transportation system can reduce exhaust 
emissions produced by private vehicles, providing a good effect on public health. Economically, bicycle maintenance is much cheaper than other modes of transportation. These three aspects are the concept of sustainability which cannot be separated from one another (Jeffrey, 2012) [1]. The provision of bicycle infrastructure has an important role, by building the right infrastructure people are tend to use bicycles more often ((Ekblad, 2016)) [2]. In December 2019, the Mataram City Government established a bicycle lane as an alternative to the community in carrying out activities along Udayana Street. The formation of cycling communities in Mataram City shows the high enthusiasm of the community in changing their lifestyle, to maintain the urban air quality and awareness of the importance of health. To support the program of the NTB Provincial Government in NTB Cycling and also accommodate the changes of transportation mode of the community from using motorbikes or cars to bicycles, it is necessary to develop bicycle lanes in Mataram City.

\subsection{Research purposes}

In general, this study aims to determine how the impact of bicycle lanes planning on the performance of roads and intersections in the study areas, the impact of mitigation at the APILL intersection toward network performance after the application of the bicycle lanes and what is needed by motorized vehicle users to switch to using a bicycle.

\section{RESEARCH METHODS}

The research is located on 9 provincial roads in Mataram City, and this research is carried out for motorized vehicle riders, active cyclists and using bicycles for daily activities, and for passive activities, such as using the bicycle only for sports on holidays, and also the stakeholders who issue the policies regarding transportation, in this case Bappeda (Agency for regional development), NTB Provincial Transportation Department and the Mataram City Transportation Service. The research location is carried out on the roads in Table 1.

Table 1 Road section of the Research Location

\begin{tabular}{|c|l|c|}
\hline No & \multicolumn{1}{|c|}{ Street Name } & Lenght of Path \\
\hline 1 & Langko & $2,3 \mathrm{Km}$ \\
\hline 2 & Pejanggik & $1,92 \mathrm{Km}$ \\
\hline 3 & Bung Hatta & $0,96 \mathrm{Km}$ \\
\hline 4 & Bung Karno & $1,09 \mathrm{Km}$ \\
\hline 5 & Sriwijaya & $1,32 \mathrm{Km}$ \\
\hline 6 & Majapahit & $2,05 \mathrm{Km}$ \\
\hline 7 & Majapahit 2 & $1,00 \mathrm{Km}$ \\
\hline 8 & Yos Sudarso & $0,85 \mathrm{Km}$ \\
\hline 9 & Airlangga & $1,58 \mathrm{Km}$ \\
\hline
\end{tabular}

The performance data of the existing roads and intersections were obtained from the Traffic Counting and CTMC surveys, while to find out the origin of the trip, Home Interview survey was carried out. In addition, secondary data in the form of geometric road data, land use and road networks were collected as input data in the Visum and Vissim programs to conduct forecasting after the development of bicycle lanes was applied to the roads that were being the study area. As an input for policy makers, a SWOT analysis was carried out by distributing surveys to people who work or live around the study area. This is done to determine the needs of people who use motorized vehicles to switch to using bicycles. 


\section{RESULTS AND DISCUSSION}

The roads study area are those which fall under the authority of the province, where the street of Yos Sudarso, Langko, Pejanggik, Majapahit and Sriwijaya are the secondary arterial roads, while street of Airlangga, Bung Hatta and Bung Karno are the primary collector roads.

\subsection{Eksisting Roard Sections Performance}

Table 2 Exsisting Road Section Performance

\begin{tabular}{|c|l|c|c|c|c|c|}
\hline No & \multicolumn{1}{|c|}{ Name } & Type & $\begin{array}{c}\text { Capacity } \\
\text { (smp/hour) }\end{array}$ & $\begin{array}{c}\text { Volume } \\
\text { (smp/hour) }\end{array}$ & VCR & LOS \\
\hline 1 & St. Langko & 3/1 UD & 4293.77 & 2467 & 0.57 & $\mathrm{C}$ \\
\hline 2 & St. Pejanggik & 3/1 UD & 4293.77 & 2475 & 0.58 & $\mathrm{C}$ \\
\hline 3 & St.Bung Hatta & $4 / 2 \mathrm{D}$ & 5239.93 & 986 & 0.19 & $\mathrm{~A}$ \\
\hline 4 & St.Bung Karno & $4 / 2 \mathrm{D}$ & 5239.93 & 1481 & 0.28 & $\mathrm{~A}$ \\
\hline 5 & St.Sriwijaya & $4 / 2 \mathrm{D}$ & 5239.93 & 1890 & 0.36 & $\mathrm{~B}$ \\
\hline 6 & St.Majapahit & $4 / 2 \mathrm{D}$ & 5239.93 & 2744 & 0.52 & $\mathrm{~B}$ \\
\hline 7 & St.Majapahit 2 & 2/1 UD & 3122.74 & 1994 & 0.64 & $\mathrm{C}$ \\
\hline 8 & St.Yos Sudarso & $4 / 2 \mathrm{D}$ & 6245.49 & 3281 & 0.53 & $\mathrm{~B}$ \\
\hline 9 & St.Airlangga & $4 / 2 \mathrm{D}$ & 4756.75 & 1808 & 0.38 & $\mathrm{~B}$ \\
\hline
\end{tabular}

From Table 2, the roads which have the best service levels are Bung Hatta and Bung Karno Street with rank A Level of Service or free traffic flow conditions with high speed and low traffic volume. Next are street of Sriwijaya, Yos Sudarso, Airlangga and Majapahit with rank B service level or steady flow, but the operating speed is starting to be limited by traffic conditions. Meanwhile, street of Langko, Pejanggik and Majapahit 2 (the crossroad Seruni to Ampenan) shows the $\mathrm{C}$ rank level of service or the flow is stable but the speed and movement of the vehicle is controlled. To do forecasting, model validation is carried out to prove whether the model that will be used to forecast travel in the plan year can be used or not. The validation model used is Chi square test. The decision is accepted (Ho is accepted) based on the calculation, if $\chi_{\text {hitung }}^{2}<\chi_{\text {tabel }}^{2}$, where $\chi_{\text {hitung }}^{2}$ is obtained by equation 12 . While $\chi_{\text {tabel }}^{2}$ is obtained from the Z-test table. From Table 3 it can be concluded that the model can be used because it is in accordance with the existing conditions with a 95\% confidence level. After the validation test is carried out, the model can be used as an application for forecasting.

Table 3 Validation model test

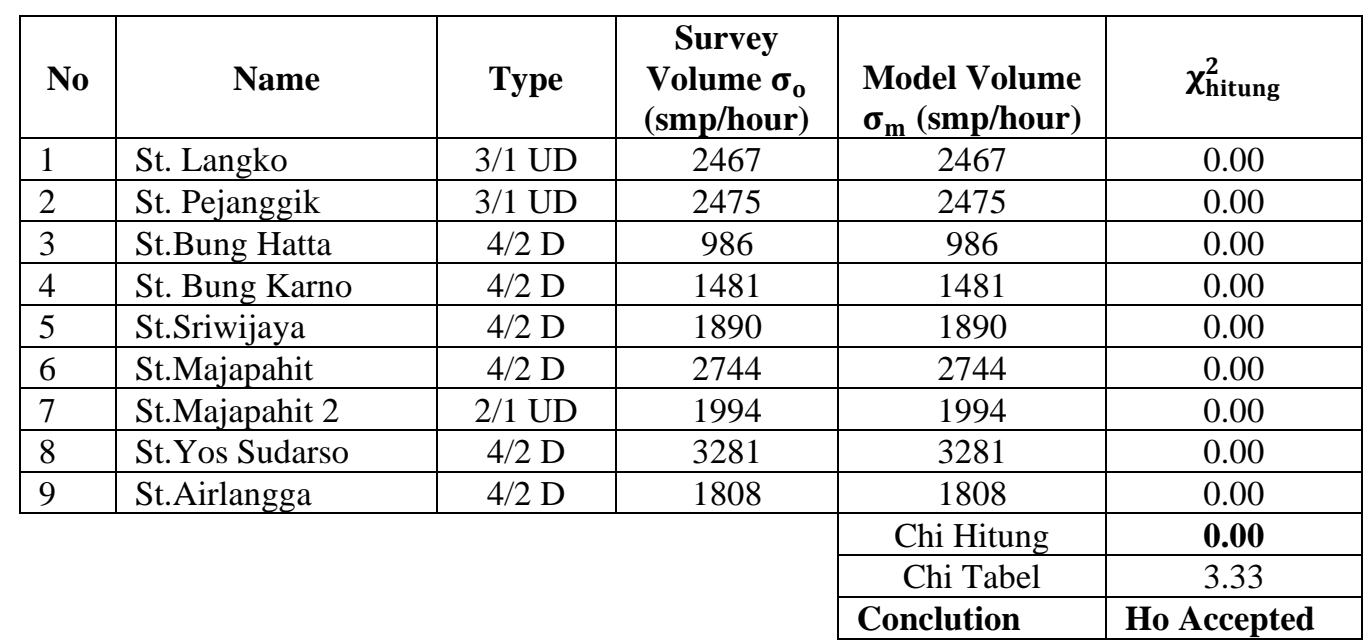


After distributing the survey form to 400 respondents who live in the 11 predefined zones, 276 data on vehicle users in each zone that definitely changed modes by bicycle were obtained, the origin of the respondents' travel destinations are shown in Table 4.

Table 4 Matrix Origin Destination (O/D Matrix)

\begin{tabular}{|c|c|c|c|c|c|c|c|c|c|c|c|c|}
\hline OD & 1 & 2 & 3 & 4 & 5 & 6 & 7 & 8 & 9 & 10 & 11 & Total \\
\hline 1 & 0 & 0 & 3 & 5 & 4 & 0 & 0 & 0 & 1 & 9 & 7 & 29 \\
\hline 2 & 0 & 0 & 0 & 0 & 5 & 1 & 2 & 0 & 0 & 14 & 8 & 30 \\
\hline 3 & 0 & 0 & 0 & 3 & 4 & 0 & 0 & 0 & 0 & 5 & 27 & 39 \\
\hline 4 & 0 & 0 & 0 & 0 & 7 & 1 & 0 & 0 & 0 & 4 & 16 & 28 \\
\hline 5 & 0 & 0 & 0 & 0 & 0 & 2 & 4 & 5 & 0 & 7 & 14 & 32 \\
\hline 6 & 0 & 0 & 0 & 0 & 4 & 0 & 5 & 1 & 0 & 2 & 13 & 25 \\
\hline 7 & 0 & 0 & 0 & 0 & 2 & 2 & 0 & 1 & 0 & 3 & 23 & 31 \\
\hline 8 & 2 & 0 & 0 & 0 & 1 & 2 & 5 & 0 & 0 & 3 & 4 & 17 \\
\hline 9 & 0 & 0 & 0 & 0 & 0 & 0 & 3 & 2 & 0 & 11 & 1 & 17 \\
\hline 10 & 0 & 0 & 0 & 0 & 0 & 0 & 0 & 0 & 0 & 0 & 24 & 24 \\
\hline 11 & 0 & 0 & 0 & 0 & 0 & 0 & 0 & 0 & 0 & 4 & 0 & 4 \\
\hline Total & 2 & 0 & 3 & 8 & 27 & 8 & 19 & 9 & 1 & 62 & 137 & 276 \\
\hline
\end{tabular}

From the matrix data of the origin destination, a desire line map was made, according to the results of the survey from the community originating from and heading to zones 1 to 11 . Based on the data obtained, most of the respondents in all zones carried out many activities to zone 11, namely Mataram 3, where the area is the center of office and school activities. The second highest activity attraction or destination area is in zone 10, namely Selaparang 3, which is in Dasan Agung Village with the center of activity being dominated by offices and schools.

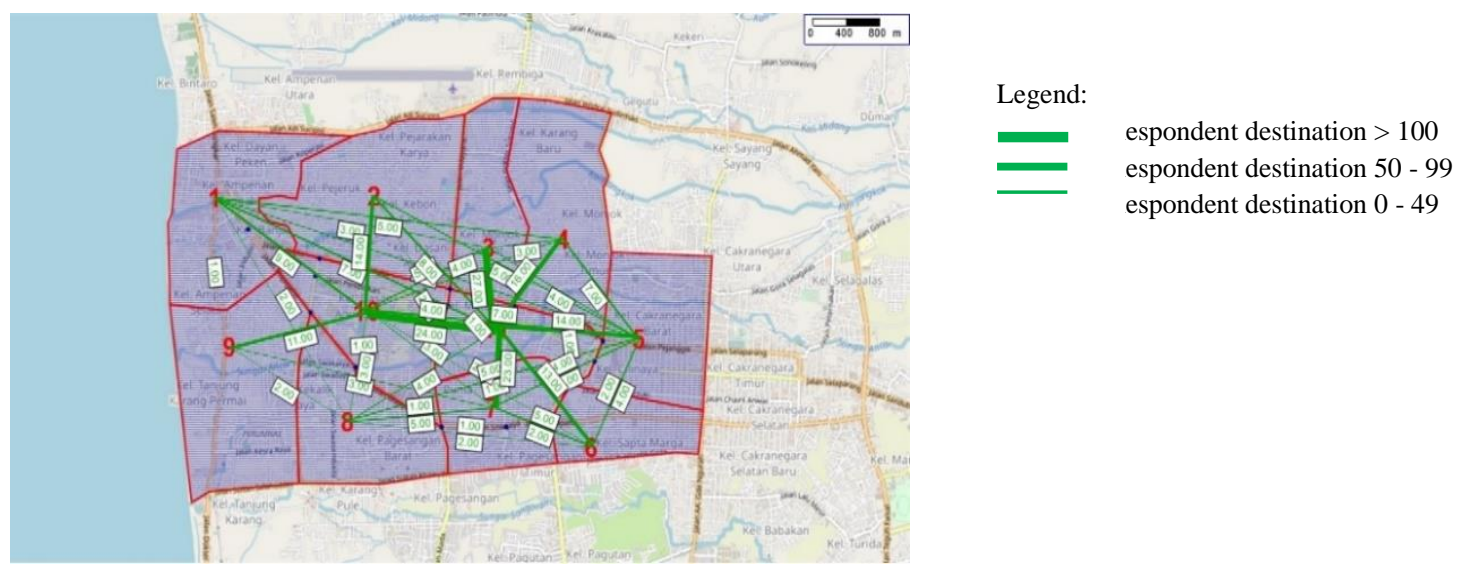

Figure 1 Desire Line of Potential Bicycle user

\subsection{Intersection Performance with Traffic Signaling Devices (APILL) Existing}

From Table 5, it can be seen that the performance at each APILL intersection is in the form of queues, delays, spent fuel consumption, and the amount of pollution produced. It can be seen in the table that the higher traffic delay value at the intersection, the higher fuel consumption is spent and the higher pollution produced. 
Baiq Musfiatin, Buan Anshari and Ir. I Dewa Made Alit Karyawan, M.T.

Table 5 Intersection Performance APILL Existing

\begin{tabular}{|l|l|c|c|c|c|c|c|}
\hline \multirow{2}{*}{ No } & \multicolumn{1}{|c|}{ Node } & $\begin{array}{c}\text { Emissions } \\
\text { CO (gram) }\end{array}$ & $\begin{array}{c}\text { Emissions } \\
\text { NOx } \\
\text { (gram) }\end{array}$ & $\begin{array}{c}\text { Emissions } \\
\text { VOC } \\
\text { (gram) }\end{array}$ & $\begin{array}{c}\text { Fuel } \\
\text { Consumption } \\
\text { (US Gallon) }\end{array}$ & $\begin{array}{c}\text { Queue } \\
(\mathbf{m})\end{array}$ & Delay (s) \\
\hline 1 & BI Intersection & 1415.69 & 275.44 & 328.10 & 20.25 & 42.43 & 68.91 \\
\hline 2 & $\begin{array}{l}\text { Gubernur } \\
\text { Intersection }\end{array}$ & 607.45 & 118.19 & 140.78 & 8.69 & 37.86 & 49.67 \\
\hline 3 & $\begin{array}{l}\text { Air Mancur } \\
\text { Intersection }\end{array}$ & 1464.05 & 284.85 & 339.31 & 20.94 & 53.95 & 80.46 \\
\hline 4 & Aston Intersection & 819.13 & 159.37 & 189.84 & 11.72 & 38.00 & 59.11 \\
\hline 5 & $\begin{array}{l}\text { Bung Karno } \\
\text { Intersection }\end{array}$ & 459.68 & 89.44 & 106.54 & 6.58 & 14.56 & 24.82 \\
\hline 6 & Mc D Intersection & 1545.28 & 300.65 & 358.13 & 22.11 & 47.60 & 69.10 \\
\hline 7 & $\begin{array}{l}\text { Epicentrum } \\
\text { Intersection }\end{array}$ & 1508.54 & 293.51 & 349.62 & 21.58 & 89.79 & 90.12 \\
\hline 8 & Seruni Intersection & 729.82 & 142.00 & 169.14 & 10.44 & 36.65 & 12.30 \\
\hline 9 & AMM Intersection & 283.06 & 55.07 & 65.60 & 4.05 & 40.25 & 19.27 \\
\hline 10 & $\begin{array}{l}\text { Airlangga } \\
\text { Intersection }\end{array}$ & 245.75 & 47.81 & 56.96 & 3.52 & 44.97 & 26.99 \\
\hline
\end{tabular}

\subsection{Existing Road Network Performance}

On 9 provincial roads in one road network in Mataram City which is become the study area, the existing condition of the speed to travel the roads on the network is $24 \mathrm{~km} /$ hour. As shown in Table 6 , the total distance traveled was $2,556.99 \mathrm{~km}$ and the total time required was 812445.20 seconds.

Table 6 Existing Road Network Performance

\begin{tabular}{|c|c|c|}
\hline $\begin{array}{c}\text { Network Speed } \\
(\mathbf{k m} / \text { hour})\end{array}$ & $\begin{array}{c}\text { Total } \\
\text { Distance }(\mathbf{k m})\end{array}$ & $\begin{array}{c}\text { Total time } \\
\text { (Second) }\end{array}$ \\
\hline 24.00 & 2556.99 & 812445.20 \\
\hline
\end{tabular}

\subsection{The Impact of Bicycle Lanes Application on Intersection Performance}

Table 7 The Road Section performance after the application of bicycle lanes

\begin{tabular}{|c|l|c|c|c|c|c|}
\hline No & \multicolumn{1}{|c|}{ Name } & Type & $\begin{array}{c}\text { Capacity } \\
\text { (smp/hour) }\end{array}$ & $\begin{array}{c}\text { Volume } \\
\text { (smp/hour) }\end{array}$ & VCR & LOS \\
\hline 1 & St. Langko & 3/1 UD & 3844.88 & 2451 & 0.64 & $\mathrm{C}$ \\
\hline 2 & St.Pejanggik & 3/1 UD & 3844.88 & 2432 & 0.63 & $\mathrm{C}$ \\
\hline 3 & St.Bung Hatta & 4/2 D & 4367.28 & 963 & 0.22 & $\mathrm{~A}$ \\
\hline 4 & St.Bung Karno & 4/2 D & 4367.28 & 1458 & 0.33 & $\mathrm{~A}$ \\
\hline 5 & St.Sriwijaya & 4/2 D & 4367.28 & 1844 & 0.42 & $\mathrm{~B}$ \\
\hline 6 & St.Majapahit & 4/2 D & 4367.28 & 2701 & 0.62 & $\mathrm{C}$ \\
\hline 7 & St.Majapahit 2 & 2/1 UD & 2691.41 & 1951 & 0.72 & $\mathrm{C}$ \\
\hline 8 & St.Yos Sudarso & 4/2 D & 5382.83 & 3265 & 0.61 & $\mathrm{C}$ \\
\hline 9 & St.Airlangga & 4/2 D & 4490.18 & 1756 & 0.39 & $\mathrm{~B}$ \\
\hline
\end{tabular}

At the comparison before and after the bicycle lane operates there are some changes in the level of road service, especially on roads that have high side obstacles. For example, street of Majapahit and Yos Sudarso, which were originally in the rank B Level of Service, after the bicycle lane was implemented the service level became $\mathrm{C}$. 


\subsection{Impact of Bicycle Path Application on Intersection Performance}

Table 8 Intersection performance after Bicycle Lanes Application

\begin{tabular}{|c|l|c|c|c|c|c|c|}
\hline \multirow{2}{*}{ No } & \multicolumn{1}{|c|}{ Node } & $\begin{array}{c}\text { Emissions } \\
\text { CO (gram) }\end{array}$ & $\begin{array}{c}\text { Emissions } \\
\text { NOx } \\
\text { (gram) }\end{array}$ & $\begin{array}{c}\text { Emissions } \\
\text { VOC } \\
\text { (gram) }\end{array}$ & $\begin{array}{c}\text { Fuel } \\
\text { Consumption } \\
\text { (US Gallon) }\end{array}$ & $\begin{array}{c}\text { Queue } \\
(\mathbf{m})\end{array}$ & $\begin{array}{c}\text { Delay } \\
(\mathbf{s})\end{array}$ \\
\hline 1 & BI Intersection & 1419.66 & 276.21 & 329.02 & 20.31 & 41.52 & 68.60 \\
\hline 2 & $\begin{array}{l}\text { Gubernur } \\
\text { Intersection }\end{array}$ & 612.58 & 119.19 & 141.97 & 8.76 & 37.75 & 56.21 \\
\hline 3 & $\begin{array}{l}\text { Air Mancur } \\
\text { Intersection }\end{array}$ & 1360.86 & 264.77 & 315.39 & 19.47 & 55.63 & 70.13 \\
\hline 4 & $\begin{array}{l}\text { Aston } \\
\text { Intersection }\end{array}$ & 740.20 & 144.02 & 171.55 & 10.59 & 38.46 & 57.66 \\
\hline 5 & $\begin{array}{l}\text { Bung Karno } \\
\text { Intersection }\end{array}$ & 537.06 & 104.49 & 124.47 & 7.68 & 20.07 & 31.47 \\
\hline 6 & $\begin{array}{l}\text { McD } \\
\text { Intersection }\end{array}$ & 1660.66 & 350.72 & 360.41 & 23.73 & 42.96 & 62.69 \\
\hline 7 & $\begin{array}{l}\text { Epicentrum } \\
\text { Intersection }\end{array}$ & 1501.14 & 292.07 & 347.90 & 21.48 & 100.97 & 105.44 \\
\hline 8 & $\begin{array}{l}\text { Seruni } \\
\text { Intersection }\end{array}$ & 742.70 & 144.50 & 172.13 & 10.63 & 39.42 & 14.47 \\
\hline 9 & $\begin{array}{l}\text { AMM } \\
\text { Intersection }\end{array}$ & 280.59 & 54.59 & 65.03 & 4.01 & 51.75 & 20.21 \\
\hline 10 & $\begin{array}{l}\text { Airlangga } \\
\text { Intersection }\end{array}$ & 239.68 & 46.63 & 55.55 & 3.43 & 46.32 & 29.67 \\
\hline
\end{tabular}

The implementation of bicycle lanes has effect the performance of intersections as illustrated in Table 8, there is an increase in queue length at 7 intersections, namely the Air Mancur Pajang, the Aston, Bung Karno, the Epicentrum, the Seruni, AMM and Airlangga Intersections. Increased time delays also occurred at 6 intersections, whice are the Governor's intersection, Bung Karno intersection, Epicentrum intersection, Seruni intersection, AMM intersection and Airlangga intersection.

\subsection{The Impact on Road Network Performance}

If bicycle lanes are implemented on the study area, there will be an increase in speed on the network and a decrease in the total distance as shown in Table 9. The total travel time has also decreased; originally the travel time on the network was 812445.20 seconds, after the implementation of the bicycle lanes it became 780266.10 second. Meanwhile, the speed on the network, which was originally $24 \mathrm{~km} /$ hour, has increased to $24.25 \mathrm{~km} /$ hour.

Table 9 Performance of the Road Network after the Application of Bicycle Paths

\begin{tabular}{|c|c|c|}
\hline $\begin{array}{c}\text { Network speed } \\
(\mathbf{k m} / \mathbf{h o u r})\end{array}$ & $\begin{array}{c}\text { Total } \\
\text { distance }(\mathbf{k m})\end{array}$ & $\begin{array}{c}\text { Total time } \\
\text { (detik) }\end{array}$ \\
\hline 24.25 & 2506.36 & 780226.10 \\
\hline
\end{tabular}

\subsection{Mitigation of Intersection with APILL}

After mitigation measures againts the impact of operating the bicycle lanes, there is an improvement in the overall performance indicator of the intersection as in Figure 2, namely the total amount of $\mathrm{CO}$ for all intersections produced was reduced from the conditions during operation 9095.13 grams to 8978.82 grams, the total number of NOx for all intersections reduced from 1797.19 grams to 1746.95 grams, the total number of VOCs for all intersections decreased from 2183.42 grams to 2080.94 grams, vehicle fuel consumption at all intersections decreased from 130.09 US gallons to 128.44 US gallons, the total queue at all intersections 
decreased from 474.85 meters to 444.65 meters, and the total vehicle delay at all intersections decreased from 500.75 seconds to 500.44 seconds.

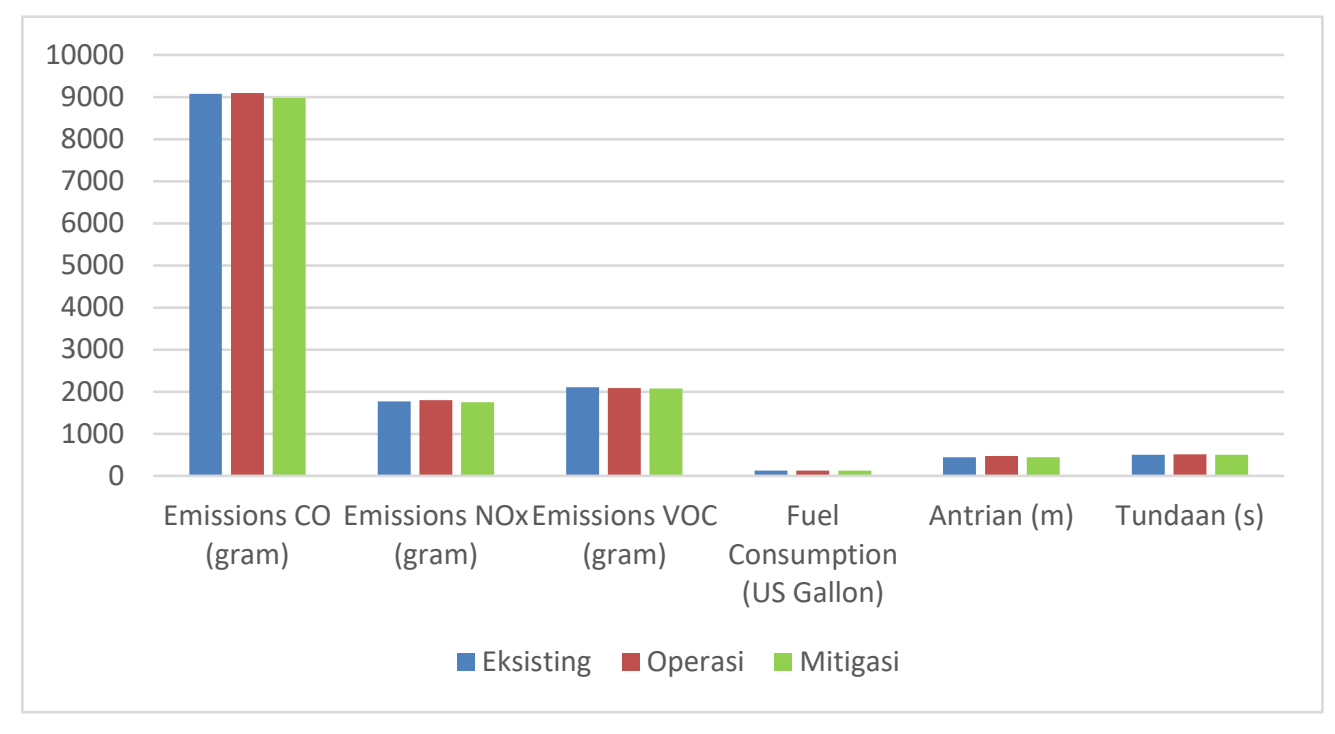

Figure 2 Intersection Service Level in Existing Condition, Bicycle Path Operation and Mitigation

\subsection{Network Performance with APILL Cycle Time Change Mitigation}

The mitigation taken to maximize the performance of the transportation system, is to change the APILL cycle time. After mitigating the change in APILL cycle time, there was an increase in network speed and a reduction in the time for all vehicles to travel in a system, but there is an additional mileage in the network transportation system. Comparison of service levels in the network system before, after the implementation of the bicycle lanes and after mitigation at the APILL intersection can be seen in Figure 3.

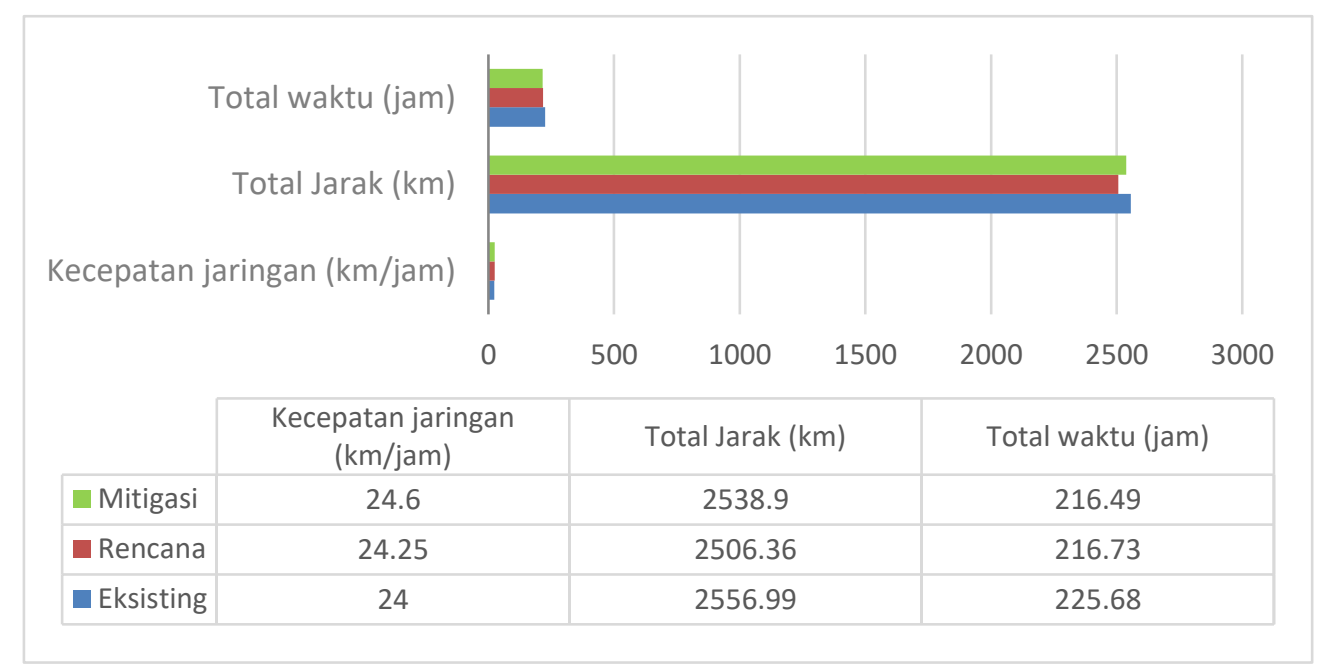

Figure 3 Network System Service Level in Existing Conditions, Bicycle lanes Operation and Mitigation.

\subsection{SWOT Analysis on Bicycle Path Development}

Overall, there are 22 people use bicycles as a daily mode. However, 20 of them, apart from using bicycles, also use 2-wheeled or 4-wheeled vehicles at any time. The cause of 2-wheeled and 4-wheeled vehicle riders who have a bicycle but have not used it as a daily mode is constrained by distance ( 15 respondents), there is no bicycle lane (11 respondents), time ( 7 
respondents) and child pick-up activities ( 7 respondents) while others are due to the tropical climate in Mataram City. Meanwhile, if seen from Figure 6, the number of respondents who are less than $5 \mathrm{~km}$ away from the house to the location of their daily activities is almost $50 \%$ of the total respondents.

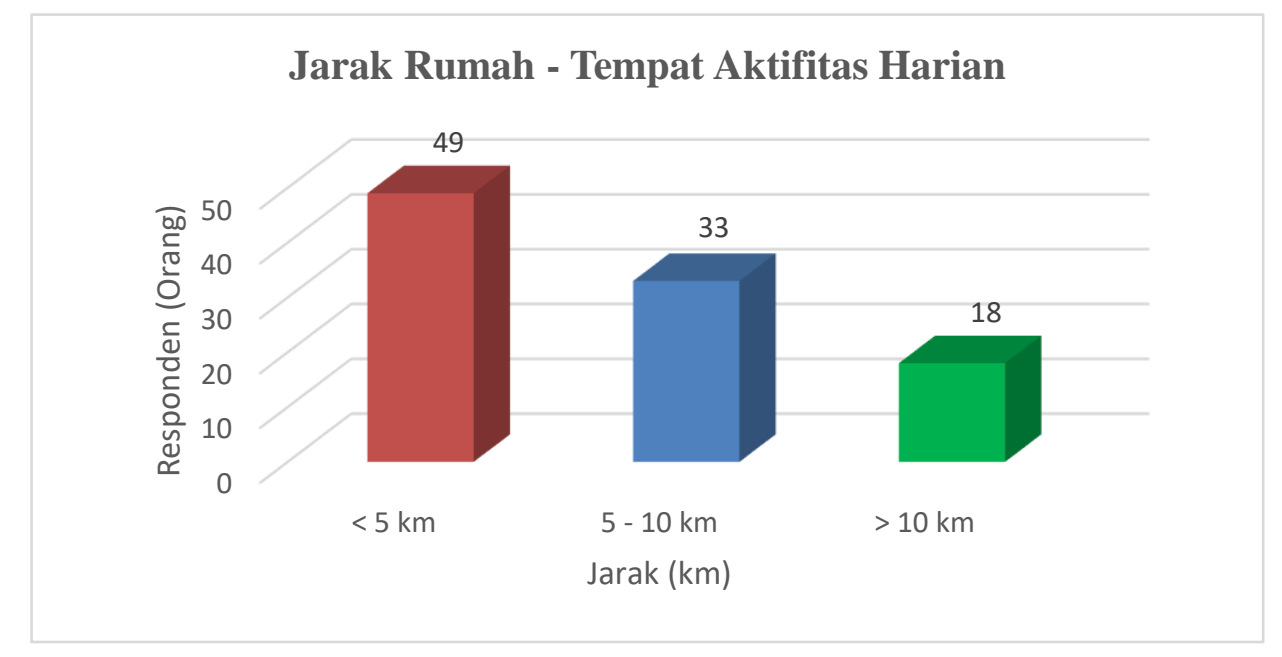

Figure 4 Distance between the house and the place of the respondent's daily activities

By implementing the bicycle lane in Mataram City, most respondents are concerned about the behavior of motorized vehicle riders, both 2-wheeled and 4-wheeled, who oftenly do not pay attention to the rights of cyclists and do not understand the function of bicycle lane facilities. The need to provide supporting facilities for cyclists, especially parking lots and changing rooms, and the absence of regulations protecting the rights of cyclists. So that from these strategic issues there are strategic initiatives that are proposed, as shown in Table 10.

Table 10 Matrix SWOT Strategy for Bicycle Path Planning Development in Mataram City

\begin{tabular}{|c|c|c|}
\hline $\begin{array}{l}\text { External Factors } \\
\text { Internal Factors }\end{array}$ & Opportunity & Threat \\
\hline Strength & $\begin{array}{l}\text { Organizing reguler National and } \\
\text { International Cycling event } \\
\text { through or with the aim of tourist } \\
\text { destination. } \\
\text { Make a collaboration with the } \\
\text { private sector to provide } \\
\text { discounts on tourist sites and } \\
\text { culinary spot for cyclists, } \\
\text { because it saves parking space so } \\
\text { as to increase the number of } \\
\text { visitors. }\end{array}$ & $\begin{array}{l}\text { Providing bicycle lanes that } \\
\text { have integrated routes with } \\
\text { other public transpotation, } \\
\text { along with supporting } \\
\text { facilities. } \\
\text { Make regulations to protect } \\
\text { the rights of cyclists in } \\
\text { traffic. }\end{array}$ \\
\hline Weakness & $\begin{array}{l}\text { Provide bicycle parking facilities } \\
\text { at tourist sites using loacal } \\
\text { materials } \\
\text { Make a collaboration with the } \\
\text { Cycle community for interactive } \\
\text { discussion with the general } \\
\text { public about the benefits of } \\
\text { cycling and the importance of } \\
\text { maintaining safety on the road. }\end{array}$ & $\begin{array}{l}\text { Cooperate with law } \\
\text { enforcement to take action } \\
\text { againts violation in other to } \\
\text { support the safety and } \\
\text { comfort of cyclists. } \\
\text { Encourage bicycle } \\
\text { entrepreneurs to provide } \\
\text { discounted in bicycle prices. }\end{array}$ \\
\hline
\end{tabular}


In determining the focus of the strategy applied for the bicycle lanes development plan in the city of Mataram, a quadrant is used where the $\mathrm{X}$-axis value is obtained from the average score of internal factors where the Strength $(S)$ score minus the Weakness score then divided by 2 and the $y$-axis with the average score of external factor, where the Opportunity score is reduced by the Threat score then the results are divided by 2 . The method of calculating the SWOT analysis strategy diagram is as follows:

$\begin{aligned} \mathrm{x} \text {-axix value } & =(\mathrm{S}-\mathrm{W}) / 2 \\ & =(2.88-2.71) / 2 \\ & =0.17 / 2 \\ & =0.09\end{aligned}$

$$
\begin{aligned}
\text { y-axix value } & =(\mathrm{O}-\mathrm{T}) / 2 \\
& =(3.07-3.11) / 2 \\
& =-0.04 / 2 \\
& =-0.02
\end{aligned}
$$

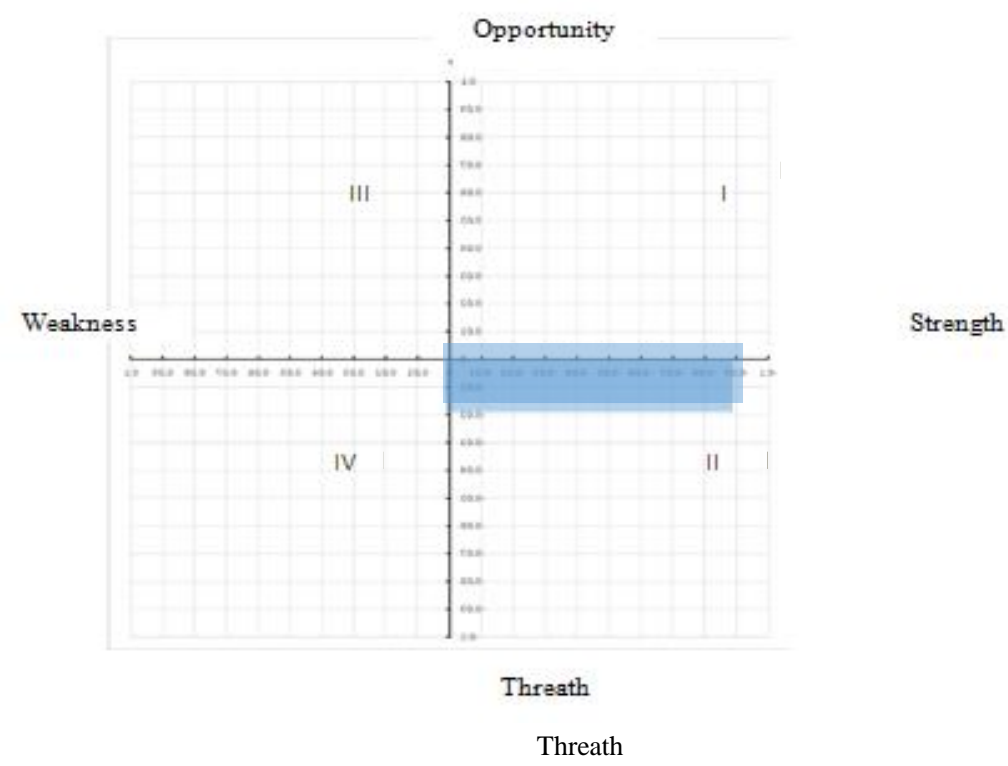

Figure 5 Strategy Diagram for the Bicycle Path Development Plan in Mataram City

The strategies to be implemented according to quadrant II are:

- Providing bicycle lanes that have integrated routes with other public transportation and supporting facilities. Because some respondents are constrained by distance, the integration of bicycle routes with public transportation, both Bus Rapid Transit (BRT) and feeder transportation, can be overcome. Likewise with security and comfort at the destination location through the provision of safe parking spaces and encouraging the provision of comfortable changing places throughout the office.

- Make rules to protect the rights of cyclists in traffic. This is done to prevent misuse of the bicycle lanes for other activities, both for parking and selling places.

\section{CONCLUSION}

- The impact of the bicycle lanes development plan policy on provincial roads which became the study area when the bicycle lane was operating was that there was a change in Level of Service (LOS) from B to C, namely on Majapahit street and Yos Sudarso street. At the APILL intersection where the bicycle lane passes, there was an increase in queue length at all intersections except $\mathrm{McD}$ intersection, $\mathrm{BI}$ intersection and Governor's junction where vehicle queues drop down to 4.6, 0.9 and 0.11 meters respectively. Whereas in the network system there was an increase in speed from 24 
$\mathrm{km} /$ hour to $24.25 \mathrm{~km} /$ hour, a decrease in the total distance from $2556.99 \mathrm{~km}$ to $2506.36 \mathrm{~km}$ and a total travel time from 225.68 hours to 216.73 hours.

- Mitigation was carried out by resetting the intersection cycle time, at the BI, Governor, McD, Epicentrum, Seruni, AMM and Airlangga intersections. By resetting the APILL cycle at the 7 intersections, there was an increase in service as indicated by reduced $\mathrm{CO}, \mathrm{NOx}$ and VOC emissions besides fuel consumption, vehicle queue lengths and vehicle delays were also reduced.

- From the SWOT analysis based on the questionnaire filled out by the respondents, what can affect the respondent's mode change from using a motorized vehicle to a bicycle is the existence of a bicycle lane with a route that is integrated with public transportation and its supporting facilities (parking, changing rooms). And regulations are needed to protect the rights of cyclists in traffic.

\section{RECOMMENDATION}

- Providing bicycle lanes with traffic signs, socializing the provision of safe parking facilities and changing clothes at the office, parking facilities in public areas and integrating bicycle routes with public transportation so that cyclists can travel longer.

- Regulate parking on roads that have bicycle lanes and provide traffic signs that regulate parking restrictions on bicycle lanes.

- Giving priority to cyclists in the crossing area by carrying out traffic management and engineering in the form of providing wider zebra crossings so that they can be used together with pedestrians, so that cyclists can cross safely and not cut off the flow of motorized vehicles that will turn left.

- Together with law enforcement officials, periodic monitoring and evaluation of the use of bicycle lanes.

- Issue local regulations that support the safety and security of bicycle users in road traffic

\section{REFERENCES}

[1] Ekblad, et all (2016) 'Bicycle planning in an urban context - A literature review', Bulletin 300, Transport and Roads, Department of Technology and Society, Lund University, (December). doi: 10.13140/RG.2.2.36461.38889.

[2] Tumlin Jeffrey (2012) Sustainable Transportation Planning. New Jersey: John Wiley \& Sons, Inc.

[3] Permenhub Nomor 13 (2014) Peraturan Menteri Perhubungan Republik Indonesia Nomor PM 13 Tahun 2014 Tentang Rambu Lalu Lintas, Kementerian Perhubungan Republik Indonesia.

[4] Permenhub Nomor 34 (2014) Peraturan Menteri Perhubungan RI Nomor PM 34 Tahun 2014 tentang Marka Jalan.

[5] PP Nomor 34 (2006) 'Peraturan Pemerintah Nomor 34 Tahun 2006 Tentang Jalan', Lembaran Negara Republik Indonesia Tahun 2006 Nomor 86.

[6] PP Nomor 79 (2013) PP Republik Indonesia Nomor 79 Tahun 2013 Tentang Jaringan Lalu Lintas dan Angkutan Jalan, Jaringan Lalu Lintas Dan Angkutan Jalan.

[7] UU Nomor 22 (2009) UU No 22 Tahun 2009 tentang Lalu Lintas Angkutan Jalan, UU No. 22 Th 2009. Jakarta. doi: 10.7202/1016404ar. 